\title{
LETTERS
}

\section{The cardiovascular risk of snowfall and snow shovelling in Canada}

I read with interest the manuscript by Auger and colleagues that was published in CMAJ. ${ }^{1}$

The major findings of their work using a large database from Quebec (administrative data) were that the quantity and duration of snowfall were associated with subsequent risk of hospital admission or death due to myocardial infarction, driven primarily by an effect in men.

About five years ago, our group published a retrospective analysis of 500 acute coronary syndromes during two consecutive winters. ${ }^{2}$ The mean age of our study population in Kingston, Ontario was $65.7 \pm 13.4$ years (range 31-94 yr) and $66.7 \%$ of the events occurred in males. Thirty-five $(7 \%)$ events were documented to have occurred following snow-shovelling. Between patients with snowshovelling-related and non-related events there were no significant differences in the prevalence of diabetes, hypertension, hypercholesterolemia or sleep apnea. Logistic regression did not show any significant group differences in age and known coronary artery disease; however, those who experienced a snow-shovelling-related event were 3.6 times more likely to have a family history of premature cardiovascular disease ( $p=$

\begin{tabular}{|c|c|c|c|}
\hline Risk factor & Significance & Odds ratio & $95 \% \mathrm{Cl}$ \\
\hline Male sex & 0.007 & 5.4 & $1.6-18.2$ \\
\hline \multicolumn{4}{|l|}{ CAD (<60 yr of age) } \\
\hline History of stable angina & 0.10 & 2.4 & $0.8-6.8$ \\
\hline $\begin{array}{l}\text { Use of } \geq 4 \text { or more } \\
\text { cardiovascular medications }\end{array}$ & 0.07 & 0.4 & $0.2-1.1$ \\
\hline $\begin{array}{l}\text { Note: } \mathrm{CAD}=\text { coronary artery disease } \\
\text { Model } \chi^{2}=34.4, p<0.001 \text {, Cox and S S } \\
\text { Reproduced from Nichols RB, McInt } \\
\text { coronary syndromes. Clin Res Cardi }\end{array}$ & $\begin{array}{l}=\text { confidence inter } \\
\text { I } R^{2}=0.069 . \\
W F, \text { Chan S, et al. } \subseteq \\
012 ; 101: 11-5 \text {. @ } 20\end{array}$ & $\begin{array}{l}\text { ove } \\
\text { ber }\end{array}$ & $\begin{array}{l}\text { isk of acute } \\
\text { Springer. }\end{array}$ \\
\hline
\end{tabular}

$0.001)$ and were 4.8 times more likely to be male $(p=0.01$ ) (Table 1$) ;^{2}$ the latter in concordance with the study by Auger and colleagues. ${ }^{1}$ Those taking more than four cardiovascular medications seemed to be protected, maybe because it had been previously recommended that they avoid this physical activity.

This manuscript about the effects of snow-shovelling and its association with cardiovascular health is welcomed, and I hope it helps in advancing clear recommendations about who should avoid this type of physical activity.

\section{Adrian Baranchuk MD}

Professor of Medicine, Cardiac Electrophysiology and Pacing, Kingston General Hospital, Queen's University, Kingston, Ont. Editor-in-Chief, Journal of Electrocardiology

- Cite as: CMAJ 2017 April 10;189:E545. doi: $10.1503 / \mathrm{cmaj} .732903$

\section{References}

1. Auger N, Potter BJ, Smargiassi A, et al. Association between quantity and duration of snowfall and risk of myocardial infarction. CMAJ 2017;189:E235-42.

2. Nichols RB, Mclntyre WF, Chan S, et al. Snowshoveling and the risk of acute coronary syndromes. Clin Res Cardiol 2012;101:11-5.

Competing interests: None declared. 